\title{
EFFECT OF METHOXYFLURANE ANAESTHESIA ON THYROID FUNCTION IN MAN
}

\author{
Tsutomu Oyama, M.D., S. Shibata, M.D., A. Matsuki, M.D., AND \\ T. KUDO, M.D. ${ }^{*}$
}

THE PRESENT STUDY was undertaken to investigate the effects of methoxyfluranenitrous-oxide anaesthesia on serum thyroxine levels. Elucidation of changes in thyroid activity as an endocrine response to acute stress could have practical application in the management of patients with abnormal thyroid function. The effects of anaesthesia per se and of individual agents on the activity of the thyroid gland have not been studied in detail, and the results of the few reports are conflicting. ${ }^{1-6}$

\section{METHOD}

Twenty-one subjects who were free from endocrine, hepatic, and renal disease were studied. Sixteen subjects underwent methoxyflurane anaesthesia for at least 40 minutes prior to operations, and the remaining five subjects served as a control group who did not receive anaesthesia. Premedication consisted of pentobarbital $100 \mathrm{mg}$ by mouth one and one-half hours before operation, meperidine $35 \mathrm{mg}$, and atropine $0.5 \mathrm{mg}$ intramuscularly one hour before anaesthesia. Anaesthesia was induced with nitrous oxide $3 \mathrm{~L} / \mathrm{min}$ and oxygen $3 \mathrm{~L} / \mathrm{min}$, and methoxyflurane was administered from a Pentec vaporizer. No barbiturate was used for induction of anaesthesia. For the maintenance of anaesthesia, methoxyflurane concentration by the Pentec dial ranged from 0.5 to 1.0 per cent. Respiration was assisted throughout the procedure.

\section{SERIES I}

The first series of studies measured the serum radioactive thyroxine levels $\left(\mathrm{I}^{131}-\mathrm{T}_{4}\right)$. Seventeen subjects were studied, ranging in age from 22 to 55 years old. They were given $50 \mu \mathrm{c}$ (approximately $1.3 \mu \mathrm{g}$ ) thyroxine $\left(3^{\prime}, 5^{\prime}-\mathrm{I}^{131}\right) \dagger$ intravenously 60 hours prior to anaesthesia. Recirculation of labelled iodine was prevented by the intramuscular administration of 1-methyl-2-mercaptoimidazole (mercasol) $10 \mathrm{mg} /$ day for four days, commencing 70 hours prior to anaesthesia. Four $\mathrm{ml}$ of venous blood were drawn from each subject: (1) in the morning at $8: 45,15$ minutes before induction of anaesthesia; (2) 20 minutes and 40 minutes after induction of anaesthesia; (3) 30 minutes, 2 hours, and 24 hours after the end of anaesthesia. Radioactivity of serum $/ \mathrm{ml}$ was counted with a well-type scintillation detector, and all counts were corrected for background and for

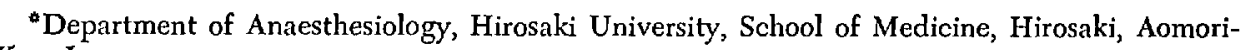
Ken, Japan.

†Supplied by Abbott Laboratories. 
physical decay to the time of administration. The results were expressed as counts $/ \mathrm{ml} / \mathrm{min}$, and then converted into radioactivity as a percentage of the value just prior to induction. Protein-bound iodine ( $\left.\mathrm{PBI}^{131}\right)$ was measured simultaneously by precipitation with trichloracetic acid.

\section{SERIES II}

Four subjects, ranging in age from 20 to 48 years of age, who underwent various operations under methoxyflurane- $\mathrm{N}_{2} \mathrm{O}$ anaesthesia, were studied. The blood sampling time was similar to that in Series I. Serum thyroxine binding ability with protein was assessed indirectly using the absorption of labelled 1-3, 3 , 5-triiodothyronine $\left(3^{\prime}-\mathrm{I}^{131}\right)$ onto a resin sponge from serum. The procedure was carried out using the Abbott Triosorb Kit according to the method of Mitchell. ${ }^{7}$

\section{RESUlts}

The level of thyroxine $\left(\mathrm{I}^{131}-\mathrm{T}_{4}\right)$ in the blood of the control group decreased gradually each day as depicted in the Table $I$ and Figure 1 . The mean blood thyroxine value of the control group just before induction was 751 counts $/ \mathrm{ml} /$ min, which was expressed as 100 per cent, and the other values were calculated as per cent in comparison with this preinduction level (Table I). The mean base line value for the methoxyflurane- $\mathrm{N}_{2} \mathrm{O}$ anaesthesia just before induction was 878 counts $/ \mathrm{ml} / \mathrm{min}$ (expressed as 100 per cent). No appreciable changes were observed in thyroxine levels in blood during anaesthesia and in the postanaesthesia period, as shown in Figure 1 and Table I.

The radioactivity of the serum and the protein-bound iodine ( $\mathrm{PBI}^{131}$ ) of the same serum sample was similar in all cases, which indicated that the alteration of blood radioactivity was due to a change in labelled thyroxine and not simply to an alteration in inorganic iodide. The ability of thyroid hormone to bind with serum protein, as determined by triiodothyroxine $\left(\mathrm{I}^{131}-\mathrm{T}_{3}\right)$ sponge uptake, was not influenced by methoxyflurane- $\mathrm{N}_{2} \mathrm{O}$ anaesthesia (Table II).

\section{Discussion}

During the methoxyflurane- $\mathrm{N}_{2} \mathrm{O}$ anaesthesia neither measurable alteration in the concentration of $\mathrm{I}^{131}$-labelled thyroxine nor appreciable change in serum binding capacity of triiodothyronine was observed by our study. The recirculation of labelled iodine was prevented by the anti-thyroid drug (mercazole), and the blood radioactivity evident was due to the labelled thyroxine as determined by measurement of protein-bound iodine ( $\mathrm{PBI}^{131}$ ). Therefore, the changes in the blood radioactivity appear to be due either to alteration in secretion of thyroxine or to the peripheral redistribution of thyroxine.

Fore et al..$^{6}$ in a similar study, by labelling thyroxine with two kinds of isotopes $\left(\mathrm{I}^{131}-\mathrm{I}^{125}\right)$, have demonstrated that there is no appreciable increase in the amount of thyroxine secretion from the thyroid gland. They postulated that ether anaesthesia caused a rapid shift of tissue-bound thyroxine into the blood. Serum bind- 


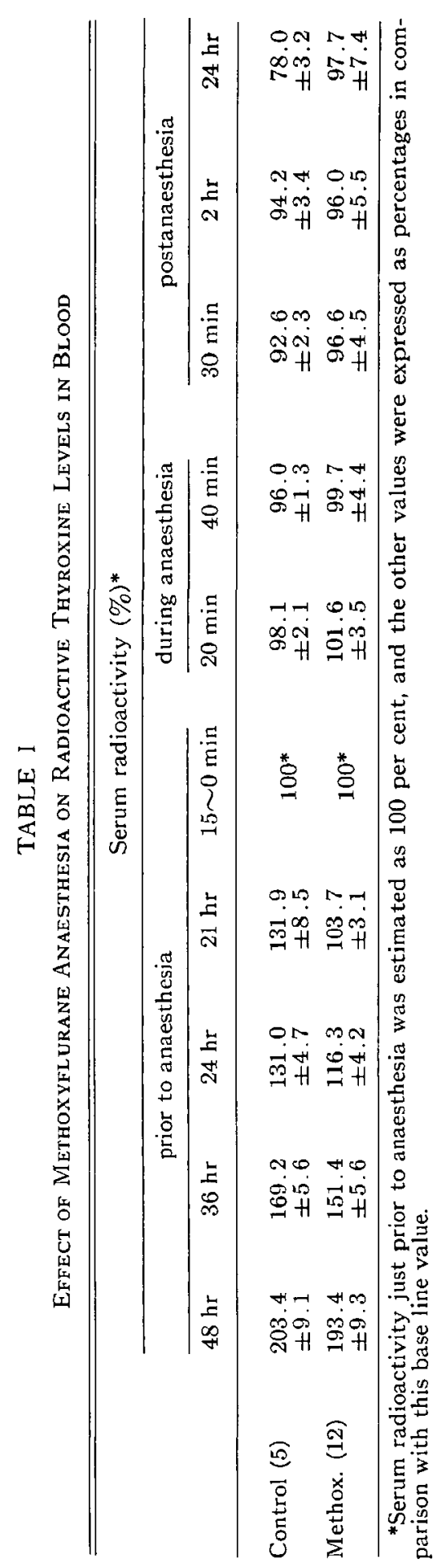




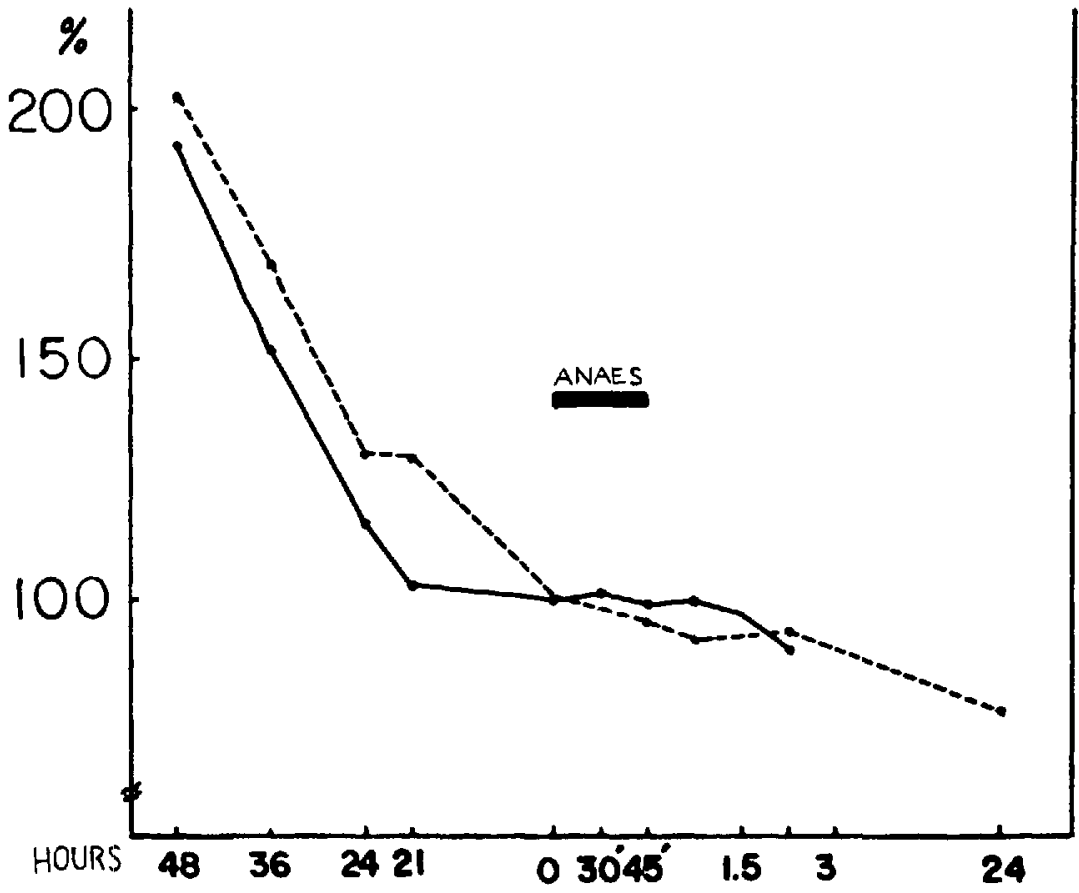

Figure 1. Plasma radiothyroxine $\left(\mathrm{I}^{131}-\mathrm{T}_{4}\right)$ levels. The solid line represents methoxyflurane anaesthesia; the broken line represents the control group.

TABLE II

Effect of Methoxyflurane Anaesthesia on Triodothyronine Resin SPONGE UPTAKE

\begin{tabular}{cccccccr}
\hline Subjects & $4 \sim 5 \mathrm{PM}^{*}$ & Preind. & Anaes. 15† Anaes. 30 & Anaes. 45 & Op. 60 & $24 \mathrm{hr}$ \\
\hline 1 & - & 28.6 & 25.9 & 25.9 & 26.0 & 28.6 & 29.6 \\
2 & 37.7 & 38.3 & 42.7 & 38.3 & 35.3 & 33.0 & 36.8 \\
3 & 33.0 & 26.2 & 27.0 & 26.7 & 31.4 & 30.7 & 31.5 \\
4 & 33.9 & 28.5 & - & 32.5 & 32.5 & 34.6 & 31.5 \\
Mean & 34.9 & 30.4 & 31.9 & 30.9 & 31.3 & 31.7 & 31.6 \\
\hline
\end{tabular}

Normal value $=25 \sim 35$ per cent.

*The value on the day before operation.

†Time in minutes.

ing of triiodothyronine is interpreted to show indirectly the capacity for binding of serum thyroxine with protein. Therefore, its value reflects not only the blood thyroxine level but also the amount of thyroxine-binding globulin in the blood.

Methoxyflurane- $\mathrm{N}_{2} \mathrm{O}$ anaesthesia appears to have failed to elicit thyroid activity, judged from the absence of a concomitant effect on the serum thyroxine level and its capacity for serum binding with protein (triiodothyronine resin sponge uptake). This is in contrast to the reported effect of ether on thyroid activity in man. ${ }^{8}$ From the clinical point of view, it would seem to be wise to choose methoxyflurane-nitrous-oxide-oxygen as an anaesthesia agent for the patient 
with hyperthyroid activity such as Basedow's disease, and to avoid ether or halothane.

\section{Summary and Conclusion}

The effect of methoxyflurane-nitrous-oxide-oxygen anaesthesia on thyroid function was studied in 21 subjects. Neither significant alteration in blood thyroxine $\left(\mathrm{I}^{131}-\mathrm{T}_{4}\right)$ level nor blood triiodothyronine $\left(\mathrm{I}^{131}-\mathrm{T}_{3}\right)$ sponge uptake was noted during anaesthesia. These findings would suggest that methoxyflurane anaesthesia has no significant influence on thyroid activity in man.

\section{RÉSUMÉ}

On a recherché l'effet de l'anesthésie au méthoxyflurane-protoxyde d'azoteoxygène sur la fonction thyrö̈dienne chez 21 sujets. On n’a décelé aucun changement important dans le niveau de thyroxine radioactive $\left(\mathrm{I}^{131}-\mathrm{T}_{4}\right)$ dans le sang, ni dans la triiodothyronine $\left(\mathrm{I}^{131}-\mathrm{T}_{3}\right)$ du sang. Ces observations portent à croire que l'anesthésie au méthoxyflurane n'a pas d’influence importante sur l'activité thyroìdienne chex l'homme.

\section{REFERENCES}

1. Oyama, T. Effects of Anesthesia on Thyroid Function of Rats. Anesthesiology. 18: 719 (1957).

2. Oyama, T. Effects of Diethyl Ether Anesthesia on Thyroid Function of Rats. Endocrinology. 65: 56 (1959).

3. Hydovirz, J. D. Effect of Anesthesia and Thyroid Surgery on the Plasma Level of PBI131. J. Clin. Endocr. 17: 76 (1956).

4. Green, N. M. \& Goldenberg, I. S. The Effect of Anesthesia on Thyroid Activity in Humans. Anesthesiology. 20: 125 (1959).

5. Johnston, I. D. Endocrine Aspects of the Metabolic Response to Surgical Operation. Ann. Roy. Coll. Surg. England. 35: 270 (1964).

6. Fore, W; KoHmer, P.; \& Wyns, I. Rapid Redistribution of Serum Thyroxine during Ether Anesthesia. J. Clin. Endocr. 26: 821 (1966).

7. Mitchell, M. L. Resin Uptake of Radiothyroxine in Sera from Non-pregnant and Pregnant Women. J. Clin. Endocr. 18: 1437 (1958).

8. Oyama, T.; Shibata, S.; \& Matsuxi, A. Thyroxine Distribution during Ether and Thiopental Anesthesia in Man. Anesth. \& Analg. 48: 1 (1969). 